\title{
Kādas nozares mantojuma un nācijas identitātes sardzē: latviešu jūrlietu vēstures izpēte un saglabāšana trimdā
}

\author{
Protecting of National Identity and Heritage of a Certain Economical \\ Sector: Research and Maintenance on Latvian Maritime History in Exile
}

\author{
Dāvis Beitlers, Mg. hist. \\ Latvijas Universitātes Vēstures un filozofijas fakultātes doktorants \\ Rīgas vēstures un kuğniecības muzeja vēsturnieks \\ Palasta iela 4, Riga, LV-1050 \\ E-pasts:davis.beitlers@tvnet.Iv
}

Rakstā sniegts neliels ieskats svarīgākajos vienas konkrētas Latvijas tautsaimniecības un kultūras vēstures jomas - jūrniecības - izpētes aspektos latviešu trimdā Rietumos pēc Otrā pasaules kara, iezīmējot arī to, kā ar šìs izpētes un ar to saistīto pasākumu palīdzību noteikta trimdas sabiedrības grupa tiecās sniegt specifisku artavu nacionālās pašapziņas uzturēšanā trimdas sabiedrībā kopumā.

Atslēgvārdi: latviešu trimda, kuğniecība, sabiedriskās organizācijas, historiogrāfija, nacionālā pašapziṇa.

The article provides a brief insight into the most important aspects of research in a distinctive field of Latvian economic and cultural history maritime history, studied by Latvian exiles in the West after the Second World War. The text also highlights how, through this research and related measures, a certain group of exiled societies tended to contribute specifically to the preservation of national self-confidence in the exile society as a whole.

Keywords: Latvian exile, shipping, public organizations, historiography, national self-confidence.

Latviešu draudžu, mākslinieciskās pašdarbības kopu un citu organizāciju darbība, iesaistī̌nanās mītnes valstu sabiedriski politiskajā dzīvē, atgādinot par Latvijas valstiskuma smago likteni Otrā pasaules kara un pēckara gados, Latvijas un latviešu pagātnes vēsturiski zīmīgāko pagātnes lappušu izgaismošana gan pašu latviešu, gan mītnes zemju pamatiedzīvotāju vidū tiklab ar akadēmiskas izpētes, kā arī publicistikas palīdzību - tādas, škiet, ir redzamākās ierosmes un darbošanās veidi, kas vērsti uz latviešu nacionālās apziņas vai pašapziņas saglabāšanu un izkopšanu trimdā. Tomēr šo ierosmju un 
darbošanās veidu ēnā nereti palicis tāds trimdinieku devums latviskās identitātes vārdā, kas, būdams ar vispārnacionālu nozīmi, pirmām kārtām bijis saistīts ar noteiktām trimdinieku grupām, kuras definē nevis dzīves telpas geogrāfiskais novietojums vai gluži ideoloǵiski raksturlielumi, bet, piemēram, profesionālās darbības lauks vai šaura interešu sfēra, kas ar kultūras nozari saistās vien netieši, pastarpināti, ja saistās vispār.

Viens no šādiem gadījumiem ir latviešu trimdas jūrniecības darbinieku centieni uzturēt svešumā latvisko garu un apzinas telpu, kopjot un daudzinot tieši savas profesionālās nozares garīgo (intelektuālo) un idejisko mantojumu, un te talkā nāca arī citu jomu speciālisti - jūrniecības ${ }^{1}$ jomas entuziasti. Šos centienus rosināja un sekmēja vairāki motīvi un apsvērumi.

No vienas puses, trimdas jūrlietu ${ }^{2}$ pārstāvju centienos kopt savas nozares nemateriālo mantojumu redzami pūliṇi, pirmkārt, radīt un saglabāt Latvijas jūrniecības vēstures naratīvu jeb stāstu kā tādu, viṇuprāt, vienīgā pareizā pagātnes traktējuma gaismā (iepretim padomju Latvijā pastāvošajam uzskatam; šeit, protams, velkamas paralēles ar trimdas historiogrāfiju un vēstures publicistiku kopumā), otrkārt netieši ${ }^{3}$ pierādīt, ka vēl vairākus desmitus gadu pēc Latvijas Republikas aneksijas un Latvijas jūrniecības nozares saskaldīšanas divās - padomju un "brīvās pasaules" noškirtās daḷās latviešu jūrniecība turpinās ne tikai okupētajā Latvijā vien un ka tikai Rietumvalstīs šis turpinājums uzskatāms par nacionālās jūrniecības nozares atvasi. ${ }^{4}$ Šim argumentam rodams dzelžains pamatojums, jo padomju Latvijā atjaunoto jūrniecības nozari grūti nosaukt par nacionālu: visas nozares struktūras, protams, izskaužot privāto kuǵniecību darbību, bija padotas vissavienības resoriem, un latviešu jūrniekus, apšaubot viņu politisko lojalitāti, tāljūras braucienos teju pilnībā aizstāja iebraucēji no plašās padomju Dzimtenes. Toties Rietumos arī pēc Otrā pasaules kara vēl aizvien darbojās latviešu rēderejas, ${ }^{5}$ gandrīz visas pasaules ūdeños kuǵoja latviešu jūrnieki - pat ja daudzkārt zem svešu valstu karogiem ${ }^{6}$ - un, galu galā, bija iespējams ideolog̣iski brīvi pētīt vai vismaz apzināt Latvijas jūrniecības vēstures liecības. Un, tā kā svešumā izklīdinātie latviešu jūrnieki un kug̣īpašnieki pirmām kārtām tomēr bija mītnes valstu tautsaimniecības daḷa un Latvijas jūrlietu vēstures entuziastu trimdā bija ārkārtīgi maz, tad šis nacionālās jūrniecības turpinājums bija ārkārtīgi trausla parādība, kas tādēl vēl jo vairāk likās sargājama un uzturama vismaz vienotas idejas veidolā, apliecinot, ka latviešu jūrlietu darbinieki un struktūras patiesi veido zināmu veselumu, uzturot kopīgu pašapziņu (par kaut kādu kopīgu tautsaimniecisko devumu trimdas saimei latviešu gadījumā - atšḳirībā no igauṇiem - runāt gandrīz nav iespējams galvenokārt profesionālās kooperācijas problēmu dēḷ). ${ }^{7}$

No otras puses, visa šì rosme bija mēǵinājums ikviena "brīvās pasaules" latvieša acīs apliecināt šādas caurcaurēm pragmatiskas tautsaimniecības nozares ideologisko nozīmi visplašākajā nacionālajā kontekstā un caur jūrlietu lauka kopšanu uzturēt arī kopējās latviskās pašapziņas druvu. Latvijas un latviešu jūrniecībai, pateicoties tās augstajiem sasniegumiem un savulaik populārajiem saukḷiem par Latviju - jūras lielvalsti, jau kopš Krišjāṇa Valdemāra laikiem piemitusi nacionālo pašapziṇu uzturoša un kāpinoša idejiskā slodze, kuru varēja izmantot arī trimdā. Turklāt, pateicoties Latvijas sūtṇa Vašingtonā Alfrēda Bīlmaņa (1887-1948) un netiešā veidā arī populārā vēsturnieka profesora Edgara Andersona darbībai (1920-1989), daḷa Rietumos nonākušās latviskās jūrniecības iemantoja Latvijas valstiskuma iespējamās atjaunotnes tautsaimnieciskā stūrakmens - vismaz viena no stūrakmen,iem - slavu. A. Bīlmanis 
un viṇa domubiedri trimdā ASV un Lielbritānijas ūdeņos pēc 1940. gada palikušos Latvijas Republikas pilsoṇu kuǵus uzskatīja par bāzi neatkarīgās Latvijas jūrniecības nozares atdzimšanai - jūrniecība bija viena no svarīgākajām valsts tautsaimniecības jomām -, de facto atjaunojot neatkarīgo Latviju. ${ }^{8}$ Savukārt E. Andersons šos pašus kug̣us līdzās Rietumu bankās noguldītajam Latvijas zeltam $\min ^{9}$ kā raksturīgu un spilgtu piemēru tiklab Rietumos nonākušās Latvijas tautsaimniecības daḷas nozīmībai, kā padomju varas pārstāvju centieniem iegūt ārpus vinu jurisdikcijas esošās Latvijas un tās pavalstnieku materiālās vērtības, kuras, nomal̦us atstājot latviešu intereses, vienlaikus centās naski izmantot vai pat izsūknēt arī pašu Rietumvalstu varas galotnes.

Tiesa gan, minētie E. Andersona pieminējumi ir tikai epizode - kaut arī spilgta - uz kopējā fona, bet A. Bīlmaņa centieni un to atbalsis publiskajā telpā caurauž tikai noteiktu trimdas perioda nogriezni. Pirmajos trimdas gados, škiet, retais atklāti šaubījās par Rietumos esošās latviešu jūrniecības dalas potenciālo nozīmi Latvijas valstiskās neatkarības atjaunošanas gadījumā - tā domāja ne vien A. Bīlmanis un viņa tuvākie domubiedri, bet arī citi Latvijas diplomātiskie pārstāvji, ${ }^{10}$ jūrniecības sabiedriskie darbinieki ${ }^{11}$ un aktīvi kuǵojošie jūrnieki; ${ }^{12}$ to sludināja publicisti trimdas mediju telpā. ${ }^{13}$ Tomēr, laikam ritot, šīs cerības, kā labi zinām, pakāpeniski noplaka un to vietā stājās agrāk, iespējams, otršķirīgā vēlme uzturēt starpkaru Latvijas jūrniecības paliekas trimdā kā apziṇas un zināmu pašapziņas telpu, uzsverot katra latviešu cilmes jūrnieka, kugiīpašnieka un Latvijas kuǵa saikni ar Latviju un latviskajām idejām. Šajā brīdī, ko varam ievērot jau 50. gadu vidū, par atslēgas jēdzienu kḷuva Latvijas jūrniecības slavenā pagātne - ne vairs nākotne saiknē ar ilgām atjaunot zudušo tēvzemi. Vēlāk, aukstajam karam norietot, trimdas jūrnieki līdzēja veidot tiltu starp jūrniecības jomām pirmajā un otrajā Latvijas Republikas valstiskās neatkarības posmā. ${ }^{14}$

Latvijas jūrniecības vēstures faktu un liecību saglabāšana un izpēte, kā arī jūrnieku piemiņas saglabāšana, reizēm sabiedriskajā telpā izceḷot arī atsevišḳu aktīvu latviešu jūrnieku devumu ${ }^{15}$ un lielākoties samērā īsi apskatot ar latviešu jūrniecību Rietumos saistītās aktualitātes, ${ }^{16}$ kḷuva par latviešu jūrniecības pārstāvju un jomas interesentu sabiedriskās darbības galveno virzienu trimdā, viṇu artavu trimdas kopienas nacionālās pašapzinas sardzē. Tas bija tiešs starpkaru laika Latvijas tradīciju turpinājums, kas šādā tematiskajā izvērsumā, kā jau ieskicēts, varēja atraisīties tikai trimdā, ne padomju okupētajā Latvijā, kur ideologiskie žnaugi, protams, traucēja kā pētìt, tā oficiāli pieminēt gan starpkaru posma kuǵniecību kopumā, gan daudzu izcilu jūrniecības personību liktenus un devumu.

\section{Individuālā jūrlietu vēstures pētniecība un daudzināšana}

Jau 50.-60. gados trimdā parādījās plašākā publiskajā telpā pamanāma interese par Latvijas jūrniecības vēstures izpēti, un tai trimdā pievērsās gan paši jūrnieki, ${ }^{17}$ gan profesionāli vēsturnieki un citu humanitāro zinātṇu pārstāvji. Izsmeḷošus reǵistrus ${ }^{18}$ par Kurzemes un Vidzemes piekrastē ūdenī nolaistajiem buriniekiem sastādījis tāljūras kapteinis Voldemārs Štāls (1908-1995; Lielbritānija), par jūrlietu vēsturi interesējies tāljūras kapteinis Alvars Mastiņš (1905-1992; Lielbritānija) un citi. ${ }^{19}$ Savu dzimtu vēsturi pētīja un grāmatās publicēja jūrnieku Zēbergu un Dambekalnu dzimtas pārstāvji - kug̣īpašnieka Kārḷa Zēberga mazdēls jurists Manfrēds Zihmanis (19112005; Kanāda) un tāljūras kapteiṇa Friča Dambekalna dēls tautsaimnieks Paulis 
Dambekalns (1917-2006; ASV); viṇu veikumā ierakstās trimdā vienīgās gluži vai monogrāfiskās pētījumu publikācijas ${ }^{20}$ par latviešu jūrniecību, kuras iznāca tiklab latviešu, kā svešās mēlēs un popularizēja latviešu jūrniecības mantojumu arī ārpus tautiešu vidus - tās atzinīgi novērtēja arī pati trimdas jūrnieku sabiedrība, netieši, tomēr nepārprotami uzteicot abu autoru ipaši M. Zihmaṇa - nopelnus latviskās pašapziņas stiprināšanā: viņi bija atgādinājuši par to, kā 19. gadsimta latviešu kuǵīpašnieki Plūdon,a atraitnes dēla centībā kḷuvuši turīgi, parādot latviešiem raksturīgo atjautību, mērkntiecību, spītu un uzñēmību. ${ }^{21}$ Savukārt tautas traǵēdiju, Latviju un tās mantu saplosot totalitāro lielvaru ugunīm, visspilgtāk apcerējis jurists un tiesību vēsturnieks Kārlis Kḷaviņš (1911-2002; Meksika): viņš savā pamatīgajā apcerē "Latvijas kug̛u likten,i"22 rakstu krājumā "Archīvs" ar akadēmisku rūpību izstaigājis ceḷus, pa kādiem pasaulē izklīduši Latvijas kug̣i un to komandas, atgādinot par abās dzelzs priekškara pusēs palikušajiem kug̣iem un kug̣iniekiem, par tiem dažiem uzṇēmīgajiem latviešiem un Latvijas Republikas diplomātiskajiem darbiniekiem (īpaši Latvijas sūtni Vašingtonā A. Bīlmani), kas aizvien centās saglabāt kaut simbolisku - parasti arī politisku un ekonomisku - Latvijas kuğu saikni ar mūsu valstiskumu. Rietumvalstīs nonākušo Latvijas kuğu problēmas ien,ēmušas redzamu vietu profesora E. Andersona interešu lokā līdztekus pazīstamajiem pētījumiem par Kurzemes hercogistes vēsturi: ${ }^{23}$ tie vistiešāk skar arī kuǵniecības vēsturi - gan Otrā pasaules kara nodarītos zaudējumus Latvijai, gan Latvijas Republikas vietu starptautiskās politikas diplomātiskajā arēnā kara laikā un pēc kara. Šeit jāizcel gan nepublicētā profesora apcere ${ }^{24}$ par Latvijas kugóiem Rietumvalstu dienestā, gan rakstu virkne, ${ }^{25}$ kas veltīta Lielbritānijas politiskajai attieksmei pret Latviju, kā arī galvenokārt ASV un Latvijas attiecībām veltītās publikācijas; ${ }^{26}$ tiesa, šajos rakstos spilgti izpaužas arī ASV dzīvojošā un šīs valsts varas iestāžu pakḷautībā savulaik strādājušā ${ }^{27}$ vēsturnieka politiskās simpātijas un antipātijas, pat zināma angažētība, atstājot visai tendenciozu iespaidu (izteikti negatīva ir viṇa attieksme pret Lielbritānijas politiku).

Ar latviešiem trimdā cieši sadarbojās arī vācbaltiešu kultūrvēsturnieks, Baltijas jūrniecības pagātnes pētnieks un aprakstnieks Heincs fon Basi (Heinz von Bassi, 1919-2003) Vācijā - viṇa spalvai pieder ne viena vien publikācija ${ }^{28}$ dažādos izdevumos vācu valodā, no kurām dậa veltīta arī citu cittautu pētnieku ${ }^{29}$ dažbrīd apskatītajai Latvijas kara flotes vēsturei.

Tomēr par spīti šai rosmei līdz galam neīstenojās domas par visaptverošu un monumentālu Latvijas jūrniecības vēsturi, kas nodarbināja ne viena vien latviešu jūrniecības darbinieka prātu; šāda nodoma vadīti, kopā sanāca Latvijas jūrniecības vēstures arhīva dibinātāji (par to tuvāk nākamajās rindkopās), šis nodoms ieskanējās latviešu publicistu rakstos prese $\bar{e}^{30}$ un trimdas jūrniecības darbinieku savstarpējā sarakstē.

Pavisam konkrētas šāda apcerējuma saturiskās līnijas savās vēstulēs amatbrālim Jānim Birzem (1915-2002; Kanāda) 60. gadu nogalē skicējis latviešu vidējās paaudzes jūrnieks Voldemārs Plosis (1905-2000; ASV), atzīstot, ka vienu pilnīgi visaptverošu darbu par laiku no pašiem pirmsākumiem tomēr neesot iespējams uzrakstīt un ka tādēḷ vajadzētu rūpīgāk apskatīt tikai noteiktu laikposmu. Kādā vēstulē J. Birzem V. Plosis pasvītro vajadzību detalizēti apcerēt dažus īpašus latviešu jūrniecības laikmetus, kuri, kā redzams, skar latviešu nacionālo jūrniecību un tālab ir arī ideolog̣iski zīmīgi:

"Pamatigāki būtu jāapskata tas sākums ar Kr. Valdemāru, tām pirmām jūrskolām, tad zēgelnieku [burinieku - D. B.] laikmetu 
lìdz 1919. gadam un pēc tam lielais uzplaukums lìdz 1939. gadam. Tad kara laiks un [laikposms] pēc kara lìdz mūsu dienām."

Tāpat V. Plosis piemin arī Latvijas seno kuǵniecību, īpaši izceḷot Kurzemes hercogistes laikmetu un seno kuršu varonību, uzbrūkot Rìgai un jūrā sakaujot bīskapa kuǵus, kā piesaukts "Indrikika hronikā", tomēr, pēc V. Ploša domām, šie senie slavas mirkḷi tomēr nebūtu jāiztirzā tik plaši kā, piemēram, burinieku un Latvijas neatkarības laikmets - kaut vai tā iemesla dēḷ, ka, piemēram, par Kurzemes hercogisti jau padziḷināti rakstījis E. Andersons, kurpretī jaunākie laikmeti palikuši otrajā plānā un tajos vēl daudz pētāmā. Tālāk seko pārdomas par materiāla izkārtošanas principiem un to, kādus aspektus izcelt, bet kādus apskatīt garāmejot. V. Plosis šai problēmai pieskaras samērā konstruktīvi, bez lieka patosa un tendenciozitātes, norādot, ka materiāli šajā aprakstā organizējami un traktējami pirmām kārtām no saimnieciskā un kopējo tautsaimniecisko tendenču viedokḷ, līdzīgi kā esot darīts Arnolda Aizsilnieka "Latvijas saimniecības vēsturē 1914-1945"; tiesa, vēstules autors tomēr atzīmē, ka tekstā, apskatot kopējās tautsaimnieciskās tendences, nedrīkstētu apiet noteiktu latviešu kuǵinieku un kuǵīpašnieku dzimtu ${ }^{31}$ nopelnus, līdztekus tirdzniecības flotes vēsturei starpkaru laikā pieminot arī valsts karafloti un tās vadon,us. ${ }^{32}$

Jau pats V. Plosis atzina, ka apkopojošas latviešu jūrniecības vēstures sacere trimdā esot gandrīz utopisks uzdevums un ka daudz reālāk esot "sastādìt tādu atminu grāmatu par tiešiem piedzìvojumiem un notikumiem kā mūsu patstāvības, tā kara laikā". ${ }^{33}$ Škiet, ka tam ir vismaz divi objektīvi iemesli, kurus V. Plosis gan tieši neatzīmē. Pirmkārt, izvērstu un vairāk vai mazāk analītisku pagātnes pētniecību, izmantojot plašu un uzticamu pirmavotu bāzi, trimdā, protams, apgrūtināja vai pat darīja neiespējamu Latvijā palikušo vēstures avotu trūkums; otrkārt, trūka pašu pētītāju, kuriem noteikti bija jābūt tiklab gana profesionāliem kādā akadēmiskā (vēlams, humanitārā) zinātnē, kā gana nenoslogotiem laika ziṇā un vienlaikus kaislīgi ieinteresētiem tieši jūrniecības vēsturē.. ${ }^{34}$ Akadēmiski izskoloto pulkā šādi reāli censoṇi neatradās pat trimdas perioda vidus posmā, kad ne viens vien graduēts latviešu cilmes vēsturnieks un kultūrvēsturnieks (tāpat kā jūrnieki) savos karjeras ceḷos jau bija tiktāl nostabilizējies vai pat tos, algotā amatā strādājot, pilnībā izbeidzis, ka vismaz teorētiski varēja sākt pievērsties arī tādai šaurai un īpatnai tēmai kā jūrniecības vēsture... Daži, kas uzdrīkstējās šo utopiju - domu par apkopojošu Latvijas jūrlietu vēsturi - vismaz daḷēji īstenot, gan atradās, tomēr vinu sekmes nebija galvu reibinošas, jo acīmredzami trūka kādas no minētajām "ideālā pētnieka" pazīmēm. Noteiktā laikposmā vistuvāk šim mērḳim tika tāljūras kapteinis Arvīds Kārklinšs (1912-1981; ASV) ar savu plašo apceri "Latvijas Republikas tirdzniecības flote 1918-1948”, kas galvenokārt tapusi 70. gados un tā arī palikusi manuskriptā; ${ }^{35}$ dienasgaismu plašākā telpā ieraudzīja vien dažas A. Kārkliṇa publikācijas $^{36}$ trimdas periodikā.

\section{Kolektīvā jūrlietu vēstures pētniecība un daudzināšana: biedrība "Latvijas Jūrniecības vēstures arhīvs"}

Pats apjomīgākais trimdinieku ieguldījums Latvijas jūrniecības vēstures izpētē ir sabiedriskās organizācijas "Latvijas Jūrniecības vēstures arhīvs" (LJVA) devums, kas arī saistīts ar panorāmiskas Latvijas jūrlietu vēstures iecerēm. LJVA 1966. gada 27. novembrī Kārdifā (Lielbritānija) dibināja seši latviešu tāljūras kaptein,i, ${ }^{37}$ un atbilstoši statūtiem šì biedrība bija bezpeḷnas organizācija, kuras 
galvenais uzdevums bija, pulcējot "brīvajā pasaulē" esošos jūrniecības vēstures entuziastus un sadarbojoties ar mītnes valstu jūrniecības vēsturniekiem, izveidot Kārdifā īpašu Centrālo krātuvi ${ }^{38}$ ar savāktajiem materiāliem, ${ }^{39}$ uz kuru bāzes nākotnē būtu iespējams "radit [apkopojošu] Latvijas jūrniecības vēsturi, starplaikā aizpildot dažus $s \bar{a}-$ pīgus robus". ${ }^{40}$ LJVA dibinātāji ar ilggadējo un aizrautīgo organizācijas vadoni Arvaldu Kalniņu (1917-2006) priekšgalā sevi neapšaubāmi uzskatīja par starpkaru Latvijā aizsāktās jūrniecības vēstures izpētes darba turpinātājiem, ${ }^{41}$ un galvenais impulss biedrības izveidei bija savulaik neauglīgi apspriestā ideja par Latvijas jūrniecības muzeju, ${ }^{42}$ kas - gan bez tālāka turpinājuma - sabiedriskajā domā sāka ieviesties līdz ar 1934. gada janvārī žurnālā "Jūrnieks" publicēto iecerētās Latvijas Jūrniecības muzeja biedrības statūtu projektu. ${ }^{43}$ Tiesa, LJVA statūtu 7. punkts lielā mērā un vismaz zināmā laika nogrieznī izslēdza šīs struktūras funkcionēšanu līdzīgi arhīvam vai muzejam mūsdienu izpratnē, kad ar šiem jēdzieniem saprotam mūžǐgas glabātavas: minētais punkts noteica, ka organizācijas "biedri ir neapstrīdami savu materiālu ipašnieki un tiem ir tiesibas tos atprasit, ja tos nodevuši Centrālā Krātuvê". ${ }^{44}$

LJVA pulcēja gandrīz visus Rietumos mītošos latviešu un Latvijas jūrlietu vēstures pētniekus, ieskaitot profesoru E. Andersonu. Organizācijā līdz tās likvidēšanai 2006. gadā darbojušies 69 cilvēki, no kuriem gandrīz $40 \%$ bija trimdā praktizējošie jūrnieki (pārsvarā virsnieki), bet pārējie latviešu jūrniecības vēsturnieki gan trimdā, gan Latvijā (pēc 1989. gada), latviešu kug̛̣īpašnieku pārstāvji, ārvalstu jūrniecības vēstures pētnieki, rakstnieki (Gunars Janovskis), latviešu trimdas garīdznieki un citi interesenti no dažādām valstīm - Lielbritānijas (51\%), ASV (13,5\%), Vācijas (10,5\%), Kanādas, Zviedrijas, Beḷǵijas un Latvijas. ${ }^{45}$ Var piekrist savulaik presē rakstītajam, ka organizācijas paspārnē bija izveidojies vesels zinātnisko līdzstrādnieku tīkls teju visās pasaules malās, ${ }^{46}$ un organizācijas darbības sākumposmā tieši biedru izkliedētība un tās sekmētās grūtības savstarpēji sazināties bija galvenais traucējošais faktors LJVA darbībā, kas ar laiku tika daḷēji pārvarēts, piesaistot jaunus līdzstrādniekus un sadarbojoties ar starptautiskajām organizācijām. ${ }^{47}$ LJVA iekšienē tās darbību koordinēja atbildīgie sekretāri Kanādā, Vācijas Federatīvajā Republikā, Skandināvijas valstīs, ASV, tā dēvētie sakaru padomnieki, kā arī administrācija - organizācijas prezidents un viceprezidents jeb generālsekretārs (faktiski - galvenais darbinieks). Pētniecisko darbu savukārt pārraudzīja zinātniski pētnieciskais padomnieks, ${ }^{48}$ un šo posteni ilgstoši ieņēma profesors E. Andersons, kura pārraudzībā gan tapa minētās LJVA biedru A. Kārkliṇa un H. fon Basi publikācijas pasaules latviešu un vietējos mītnes valstu laikrakstos, gan tika atspogul,ots organizācijas darbs 3. Baltijas studiju konferencē Stokholmā 1975. gada jūnijā. ${ }^{49}$ Skicējot sabiedriskos ieguvumus no LJVA darbības, jāpiemin fakts, ka šìs organizācijas savāktie vēstures materiāli ne reizi vien lieti noderēja arī trimdā mītošajiem latviešu kug̣īpašniekiem un viṇu mantiniekiem cīṇā par to, lai Rietumu lielvalstu valdības, ippaši Lielbritānijas varasvīri, neaizmirstu latviešu īpašumtiesības un Otrā pasaules kara laikā pārņemtos Latvijas Republikas pavalstnieku kugus atdotu to likumīgajiem īpašniekiem, vismaz izmaksājot pienācīgas kompensācijas par pārṇemtajiem peldlīdzekliem.

Tomēr par spīti šai rosībai un tam, ka pirmo desmit darbības gadu laikā ar lielu entuziasmu $^{50}$ bija izdevies apkopot ziņas par aptuveni 1000 kuğiem, simtiem dokumentu par Latvijas jūrskolām, ostām, jūrniekiem, atmiņas, dokumentus un fotogrāfijas no latviešiem teju visā pasaulē, ${ }^{51}$ nav iespējams runāt par LJVA darbības 
vainagojumu nedz apkopojošas Latvijas jūrniecības vēstures konceptuālā izstrādē, nedz arī Centrālās krātuves pilnīgā izveidē, ko neḷāva īstenot organizācijas darbības apsīkums Trešās atmodas gados, - pārāk daudz vēl bija veicams materiālu sistematizācijā un balto laukumu aizpildīšanā. Nelaime arī tā, ka gan informatīivi, gan arhīvistiski un muzejiski ${ }^{52}$ šis visnotal cienījamais krājums veidojās ārkārtīgi neviendabīgs: līdzās fotogrāfiju oriǵināliem, rokrakstiem un dokumentiem tajā kārtojās mūsdienās samērā viegli pieejamu laikrakstu izgriezumi un dažādas kvalitātes kopijas - tādas, kas gūtas gan no unikāliem oriǵinālmateriāliem un tādēl var dot pētniekam vērtīgas ziṇas (iespējams pat, ka origināls vairs nav saglabājies), gan no plaši tiražētiem izdevumiem. Blakus nogūlusies unikāla oriǵinālfotogrāfija un kserokopija neciešamā kvalitātē - teju vai nav iespējams nojaust, kur nu vēl sazīmēt attēlā redzamo objektu (uzlūkojot šādu kopiju, mēdz rasties pārdomas par to, cik pārdomāts bijis šì vākuma veidotāju darbs). Tomēr, lai gan atškirīgo autentiskuma pakāpju un kvalitātes dēḷ nevar sacìt, ka viss savāktais būtu kultūrvēsturiski augstvērtīgs un neaizstājams, jau pats fakts, ka tas viss ticis savākts vienkopus, ir atzīstams panākums, gluži tāpat kā biedrības pamatideja. Augstu vērtējama ir arī tolaik, arhīva veidošanas brīdī, vēl dzīvo vecākās paaudzes jūrnieku liecību fiksācija, ${ }^{53}$ kas citādi droši vien nebūtu notikusi, pat ja škiet, ka vēl lielāku vērti šis organizācijas darbības virziens - laikabiedru liecību ievākšana būtu iemantojis tad, ja lielāka vērība būtu pievērsta aktuālajām norisēm - latviskās jūrniecības procesu dokumentācijai pašā trimdā - pēckara Rietumu pasaulē, kaut vai apzinot iespējami vairāk tādu latviskas cilmes jūrniecības darbinieku, kas jau piederēja drīzāk jaunajām trimdinieku paaudzēm un ar Latvijas tirdzniecības flotes likteni vairs nebija saistīti.



1. att. Latvijas jūrniecības vēstures arhīva ǵenerālsekretārs Arvalds Kalniṇš (pa kreisi) un vācbaltu jūrniecības vēsturnieks Heincs fon Basi Šlēsvigā, Vācijā 1998. gadā. Foto no Rīgas vēstures un kuǵniecības muzeja krājuma.

Fig. 1. General Secretary of the Latvian Maritime History Archives Arvalds Kalniņš (on the left) and Baltic German maritime historian Heinz von Bassi in Schleswig, Germany in 1998. Photo from collection of Museum of the History of Riga and Navigation.

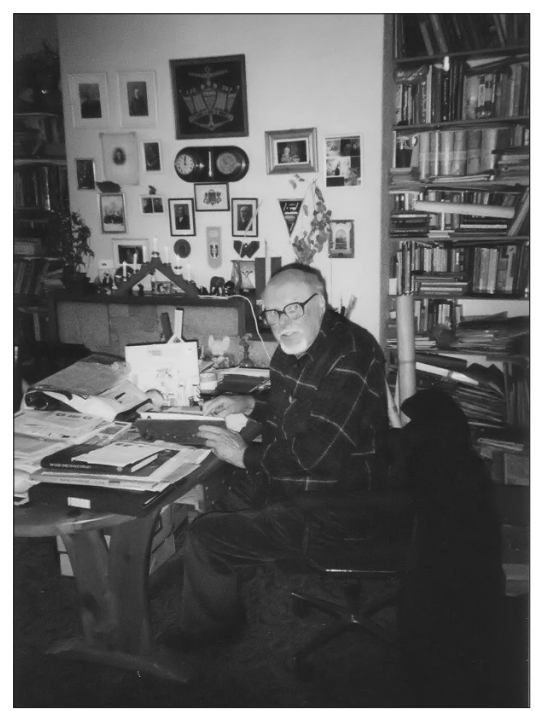

2. att. Latvijas jūrniecības vēstures arhīva ǵenerālsekretārs Arvalds Kalniṇš savā mājas kabinetā Kārdifā 2002. gadā. Foto no Rīgas vēstures un kuǵniecības muzeja krājuma.

Fig. 2. General Secretary of the Latvian Maritime History Archives Arvalds Kalniņš at the office in his home, Cardiff, in 2002. Photo from collection of Museum of the History of Riga and Navigation. 
LJVA, kaut gan allaž itin kā nīcis trimdas lielo norišu arēnas nomalē, pelnījis zīmīgu vietu ne vien Latvijas jūrlietu vēstures mantojuma saglabāšanas un izpētes vēsturē, bet arī visas trimdas kultūras zvaigznājā - līdzās, piemēram, Latviešu mūzikas krātuvei Austrālijā tā bija viena no nedaudzajām latviešu trimdas organizācijām, kas uzkrāja un arhivēja tematiski noteiktu Latvijas un latviešu kultūras mantojuma daļu, kamēr daudzo trimdas latviešu centru un centrālo struktūru bibliotēkās un arhīvos pamatā saplūda plaša spektra kultūras norišu un kopējās trimdas dzīves laikmeta dokumenti. Tāpat LJVA, pēc tautsaimnieka A. Aizsilnieka iedalījuma, neapšaubāmi uzskatāms par tā saucamo specializēto organizāciju, kas trimdā pulcēja aizrautīgus savas jomas vai tēmas entuziastus, atstājot tematiski šauru, bet konkrētu un paliekamu intelektuālo devumu trimdas un visas nācijas kontekstā. Tādu organizāciju trimdas milzīgajā biedrību un apvienību svītā bija absolūts mazākums iepretim tā dēvētajām universālajām biedrībām, kuru uzmanības centrā bieži bija latviešu saviesīgā dzīve un kuru darbība bieži rādījās daudzaptveroša, taču vienlaikus arī pārlieku vispārīga un sekla. ${ }^{54}$

\section{Jūrlietu vēstures daudzināšana ārpus nozares profesionālu un pētnieku loka}

Latviešu jūrniecības vēstures izgaismošanā un saglabāšanā, kā arī visas trimdā aizrautās latviešu nācijas daḷas pašapziṇas sekmēšanā ar jūrlietu vēstures spožāko piemēru palīdzību piedalījās ne tikai paši jūrniecības darbinieki un daži akadēmisko jomu pētnieki vai literāti, kas cieši sadarbojās ar jūrlietu darboniem, bet arī entuziasti no pārējām latviešu trimdas aprindām un sabiedriskajām organizācijām. Viṇi jūrlietu vēstures izpētei ḷāva ieaugt tautiešu sabiedriskajā dzīvē, galvenokārt uzturot latviešu jūrnieku piemiṇu - dažbrīd visai plaši un vērienīgi.

Tā, piemēram, 1986. gadā, jau trimdas perioda nogalē, plaši pasaules latviešu sabiedrībā izskanēja ziṇas par 15 latviešu jūrnieku piemiņas saglabāšanas pasākumiem, kurus Lielbritānijā iniciēja latviešu trimdas jaunatnes sabiedriskās organizācijas; šie jūrnieki bija gājuši bojā Latvijas tvaikona "Helena Faulbaums" katastrofā 1936. gadā Skotijā, un $11^{55}$ no tiem bija apbedīti turpat Kilčatanas (Kilchattan) kapsētā Luinga (Luing) salā. 1983. gada maijā salu apmeklēja Eiropas Latviešu jaunatnes apvienības (ELJA) jauniešu grupa, bet rudenī - ievērojamais grāmattirgotājs, skautu kustības vecskauts un viens no latviešu skautu vadītājiem Lielbritānijā, ${ }^{56}$ Nikolajs Doičevs (1918-2005). ${ }^{57}$ Par to, ka latviešu jūrnieku piemiņu kopj jaunā latviešu paaudze trimdā, īpaši gandarīts bija sirmais tāljūras kapteinis un LJVA generālsekretārs A. M. Kalniņš, vēstulē ELJA Anglijas nodal̦as valdes priekšsēdim Rolandam Blezūram norādot, ka jaunajiem šādās aktivitātēs laiks "pārṇemt stafeti": "Priecājos lo loti, ka jaunā audze šo braucienu velta [...] Latvijas jūrnieku pieminai, no vecās tas gandrī neiedomājami." 58 Abos apmeklējumos tika konstatēts, ka veco, 1938. gadā uzstādīto pieminekli bojāgājušajiem jūrniekiem smagi sabojājis jūras klimats: akmens apsūbējis, iekaltie jūrnieku vārdi kḷuvuši nesalasāmi. ${ }^{59}$ Un, lai to novērstu, 1985. gadā, kad tuvojās kug̣a bojāejas piecdesmitā gadskārta, N. Doičevs uzsāka plašu ziedojumu vākšanas kampaṇu pieminekḷa atjaunošanai, kas kopumā izmaksāja 850 mārciṇu. ${ }^{60}$ Teju apbrīnojama ir aizrautība, ar kādu N. Doičevs nodevās šim uzdevumam: aicinājumi līdzdarboties - gan ar līdzekḷiem, gan vēsturisko informāciju par kritušajiem jūrniekiem $^{61}$ - tika adresēti vairākiem desmitiem latviešu sabiedrisko organizāciju un privātpersonu kā Lielbritānijā, tā citur "brīvajā 
pasaulē", un atsaucību izrādīja gan vairākas Daugavas Vanagu apvienības nodaḷas, gan vietējās latviešu draudzes, gan Latviešu nacionālā padome Lielbritānijā, gan citi labvēli. ${ }^{62}$ Vienlaikus ar domu par pieminekḷa atjaunošanu radās arī ideja svinīgi atzīmēt pusgadsimta bojāejas gadskārtu, un jau 1983. gadā šo domu, vēlāk vadību uzn,emoties N. Doičevam, uzsāka virzīt ELJA Anglijas nodaḷa. ${ }^{63}$ Sarīkojums ar garīgo aktu, kura norisi nodrošināja arī vietējā (salā esošā) skotu draudze un tā sauktā Salas komiteja, ${ }^{64}$ notika 1986 . gada 13 . septembrī, piedaloties Lielbritānijas latviešu, skotu un angḷu organizāciju pārstāvjiem, kā arī vairākiem luterāṇu garīdzniekiem. Sarīkojums, saukts par Svētceḷojumu, tika plaši atainots gan "brīvās pasaules" latviešu, gan britu presē, uzsverot notikuma lielo simbolisko lomu divu tautu - latviešu un britu - draudzības stiprināšanā. ${ }^{65}$ Jāatzīmē, ka tradīcija rīkot šādus svētceḷojumus uz Luinga salu turpinājās arī vēlāk: tā, piemēram, 1989. gada 3. jūnijāâ ${ }^{66}$ un 13. septembrī̄ ${ }^{67}$ nu jau Trešās atmodas noskaņās kapsētā un vietējā baznīcā atkal norisa plaši svētbrī̌̌i, pieminot dzelmē aizrautos latviešu jūrniekus.

Latvijas un latviešu jūrniecības pieminas sabiedriskajā uzturēšanā neapšaubāmi ieklaujas arī vēsturnieka E. Andersona iniciētā un organizētā Kurzemes hercogistes jūrniecības vēstures izpēte un atcere, kas izpaudās ne tikai publikācijās, bet arī sarīkojumu organizēšanā - tika rīkotas, piemēram, starptautiskas zinātniskas konferences, veltitas Kurzemes hercogistes jūrniecības un koloniju vēsturei, organizēti Tobāgo salas kolektīvi apmeklējumi. ${ }^{68}$ Interesanti, ka izcilo vēsturnieku, kuru pazīstam arī kā zinīgu jaunāko laiku un Latvijas Republikas politiski militārās vēstures speciālistu, pievērsties jauno laiku un Kurzemes hercogistes tematikai pamudinājusi attieksme pret jaunāko laiku Baltijas politisko vēsturi kā ideologiski pārlieku jūtīgu un neērtu tematu, no kura labāk izvairīties, pievēršoties senāku un līdz ar to politiski neitrālāku laikmetu izpētei Latvijas vēsturē, - tāda nostāja E. Andersona darbības sākumā 20. gadsimta 60. gados valdīja ASV. ${ }^{69}$ Ja tā nebūtu bijis, vai E. Andersons būtu vairāk devis arī Latvijas jaunāko laiku jūrniecības vēstures izgaismošanā?

\section{Trimdas jūrlietu vēstures pētnieku veikums atjaunotajā Latvijas Republikā}

Gluži jaunu nozīmi un skanējumu iepriekšminētajiem centieniem pieškīira trimdas posma norieta gadu procesi. Sabrūkot dzelzs priekškaram, trimdā uzturētā latviskās jūrniecības vēsturiskā atmina iekḷāvās atjaunojamās Latvijas Republikas intelektuālajā un arī sabiedriski politiskajā dzīvē.

Vēstures izpētes un apzināšanas laukā Latvijas pētnieku sadarbība ar Rietumu pētniekiem sākās vēl aukstā kara laikā. Jau 80. gadu vidū Rīgas vēstures un kug̣niecības muzeja (RVKM) Latvijas kuǵniecības vēstures nodaḷas (LKVN) darbinieki sāka sadarboties ar H. fon Basi ideologisiski samērā neitrāla Latvijas jūrniecības vēstures perioda - 19. gadsimta - kug̣u un jūrnieku likteņu apzināšanā, muzejniekiem precizējot ziṇas un papildinot muzeja krājumu, ${ }^{70}$ bet Trešās atmodas gados aizsākās arī sadarbība ar citiem pētniekiem un sabiedriskajiem darbiniekiem - LJVA biedriem un amatpersonām, īpaši ar tās ǵenerālsekretāru A. Kalniṇu. No 1989. līdz 1996. gadam organizācijas biedru pulkā tika uzṇemti pieci Latvijas pētnieki: Arvis Pope (1933-2007) (Latvijas Kultūras fonda (LKF) Jūrniecības vēstures kopas (JVK) vadītājs), Jānis Hartmanis (jūrniecības vēstures pētnieks), Erna Zubova (jūrniecības vēstures pētniece), Ilze Bernsone (RVKM LKVN vadītāja) un Inta Kārkliņa (RVKM LKVN darbiniece). ${ }^{71}$ A. Popes pārstāvētā LKF JVK, kas darbību 
pārtrauca 1994. gadā, šajā laikā līdztekus RVKM LKVN kḷuva par otro institūciju Latvijā, kas nodrošināja trimdas jūrniecības pētnieku saikni ar Latviju: A. Pope aicināja latviešu jūrniekus trimdā iesaistīties pētniecības darbā Latvijā, ${ }^{72}$ ziṇoja viniem par jau paveikto un vēl iecerēto jūrniecības vēstures izpētē, ${ }^{73}$ 1991. gada aprīlī un maijā apmeklēja tautiešus svešumā ASV, apgaismojot interesentus par LKF un JVK darbību. ${ }^{74}$ Vizìti (ne vienu vien) nepalika parādā arī trimdinieki: gan LJVA biedri (Arvalds un Rūta Kalniņi, LJVA biedrs tāljūras kapteinis, rosmīgais sabiedriskais darbinieks Imants Balodis (1924-2001) Kanādā u. c.), gan citi trimdas jūrniecības sabiedrības pārstāvji ne reizi vien viesojušies Rīgā, par galveno tikšanās vietu izraugoties RVKM LKVN telpas. ${ }^{75}$

Sākotnēji trimdas un Latvijas pētnieku sadarbība notika, abām pusēm - LJVA un RVKM LKVN kopā ar JVK - sastrādājoties kā līdzīgam ar līdzīgu, taču jau pavisam drīz pēc Latvijas neatkarības pilnīgas atjaunošanas - 90. gadu vidū - A. Kalniņam kḷuva skaidrs, ka, LJVA biedriem novecojot un pamazām aizejot mūžībā, arhīvam vairs nav gaidāms ilgs mūžs un ka vajadzētu apsvērt vākuma nodošanu kādai struktūrai Latvijā. "Archìva liktenis ir visā drïzumā jāizšķir, jo vairums biedru, arī vadība, ir sasnieguši cienijamu vecuma pakāpi, kura gan nenozīmē cienijamu darba spēju pakāpi," ar skumju ironiju 1993. gadā I. Bernsonei rakstīja A. Kalniņš. Jau 1991. gada 20. novembrī no Kārdifas uz Latviju ar Latvijas kug̣niecības motorkuǵi "Inženieris Kreilis"77 tika izsūtītas 13 uzskaitītas materiālu kopas ar vairākiem tūkstošiem materiālu, par kuru formālo glabātāju tika nozīmēta LKF JVK ar A. Popi kā atbildīgo glabātāju, ${ }^{78}$ vinš̌ savukārt drīz nodeva materiālus faktiskā glabāšanā RVKM LKVN. ${ }^{79}$ Tomēr vēl dažus turpmākos gadus šis krājums aizvien nebija pārgājis RVKM īpašumā, un sarakstē ar LKVN vadītāju I. Bernsoni A. Kalniṇš vēl dēvē muzeju par materiālu pagaidu mājvietu, ieceḷot I. Bernsoni par tābrīža atbildīgo materiālu glabātāju, bet pieḷaujot, ka teorētiski šos materiālus varētu glabāt arī citviet Latvijā - piemēram, Ainažos, Engurē vai kādā citā vietā, kas vēsturiski saistīta ar jūrniecību. ${ }^{80}$ Arhīva liktenis izšḳīās 1994. gadā, kad beidza pastāvēt LKF JVK, un vēl pēc nepilna gada, 1995. gada 20. jūnijā, tika parakstīts oficiāls pien,emšanas-nodošanas akts par materiālu nodošanu RVKM LKVN un to ieklaušanu nodalas zinātniskajā arhīvā. ${ }^{81}$ 2006. gada oktobrī, aizejot mūžībā A. Kalniņam, LJVA kā organizācija Kārdifā oficiāli izbeidza savu darbību, un turpmāko gadu laikā ar A. Kalniņa atraitnes R. Kalniņas gādību uz Latviju atcel̦oja un līdz 2012. gadam RVKM LKVN krājumā un nodaḷas arhīvā iegūla vēl vairāk nekā 300 vēstures liecību. ${ }^{82}$ Daḷa 1991. gadā Latvijai nodotajā fondā neiekḷauto materiālu no Kārdifas vēl LJVA darbības laikā sasniedza RVKM LKVN I. Bernsones un A. Kalniņa ilgstošas sarakstes gaitā, sākot ar 1989. gadu. ${ }^{83}$

\section{$* * *$}

Kaut arī veikums Latvijas un latviešu jūrniecības vēstures pētniecībā un piemiņas saglabāšanā nekad nav ilgstoši gozējies trimdas sabiedrisko norišu un intelektuālā devuma priekšplānā, arī šīs ierosmes padara nozīmīgas vai vismaz simboliskas un emblemātiskas tiklab to idejiskie un ideolog̣iskie izejas punkti, kā arī galveno virzìtājpersonu apsveicamais entuziasms un augstas raudzes humanitāro zinātṇu pārstāvju (vēstures profesora E. Andersona un jurista K. Kḷavina) iesaistīšanās šajā darbā.

20. gadsimta 90. gadu ieskaṇā atdzimstot Latvijas Republikai, trimdā piekoptās Latvijas jūrlietu atmiņas kopšanas rezultāti, kā jau minēts, ieplūda un iekḷāvās atjaunotās valsts jūrniecības pagātnes 
izgaismošanā, kā arī Latvijas vēstures un kultūrvēstures pētniecības apritē kopumā. Rịgas vēstures un kuǵnniecības muzejā daḹji uz pakāpeniski saṇemto LJVA un trimdas privātpersonu piedāvāto ziṇu un materiālu bāzes jau 90. gadu vidū 21. gadsimta sākumā tapa fundamentāls uzziṇu izdevums - enciklopēdija "Latvijas jūrniecības vēsture" ${ }^{84}$ divos sējumos (īpaši svarīgi trimdā gūtie materiāli bija pirmā sējuma izstrādē). Ievērojamais trimdas tāljūras kapteinis I. Balodis - arī Latvijas jūrniecības vēstures entuziasts - ar visām savām zināšanām un rietumniecisko pasaules uzskatu aktīvi iesaistijā̄s Latvijas Republikas jūrniecības jomas atdzimšanā - gan intelektuālā, gan gluži praktiskā nozīmē.

\section{ATSAUCES UN SKAIDROJUMI}

${ }^{1}$ Absolūtais vairākums Latvijas un latviešu jūrniecības vēstures pētniecisko ierosmju un rezultātu skar Latvijas un tās teritorijas tirdzniecības floti un tās darbiniekus dažādos laikos - proti, jūrniecību kā tautsaimniecības jomu. Kara flotes un jūrnieku vēsture zināmā mērā ir savrupa joma, kas, pētot Latvijas un latviešu jūrniecības vēsturi, allaž - ne tikai trimdā - skarta tikai nedaudz, garāmejot.

${ }^{2}$ Jēdziens "jūrlietas" rakstā lietots kā vārda "jūrniecība" sinonīms.

${ }^{3}$ Paši trimdinieki šo aspektu tādā veidā nekad nav atklāti formulējuši, tomēr tas jūtams zināmā kontekstā, analizējot plašu avotu klāstu.

${ }^{4}$ Atcerēsimies, ka padomju Latvijā pēckara gados atjaunoto jūrniecības nozari vismaz pirmajās pēckara desmitgadēs grūti nosaukt par nacionālu. Tuvāk sk.: DĀVIS BEITLERs. Latviešu kuǵi un jūrnieki Rietumvalstīs varu krustpunktos: latviešu jūrniecības trimdā 1940.-1948. gadā. In: VALDA PĒTERSONE (galv. red.). Vēstures lūzumpunkti un robežšḳirtnes arhīvu dokumentos: Latvijas Valsts vēstures arhīva zinātniskie lasījumi IV. [Rakstu krājums.] Rīga 2018, 178.-179. lpp.

${ }^{5}$ Tuvāk sk., piem.: DĀVIS BEITLERs. Ieskats Graudu gimenes rēderejas darbībā trimdā. In: Latvijas Universitātes Žurnāls. Vēsture 2017, Nr. 4, 112.-125. lpp.

${ }^{6}$ Plašāk sk., piem.: DĀvis BeItLERS. Latviešu jūrnieks tālos ceḷos. In: ANITA FreiBERGA (red.). Latvijas Jūrniecības Gadagrāmata 2017. Rīga 2018, 422.-433. lpp.

${ }^{7}$ Tuvāk sk.: DĀVIS BEITLERS. Latviešu profesionālās apvienības trimdā: jūrniecības nozares piemērs. In: Latvijas Universitātes Žurnāls. Vēsture 2018, Nr. 5, 81.-99. lpp.

${ }^{8}$ Plašāk sk., piem.: DĀVIS BeITLERS. Latvijas kuği otrpus "dịkim” un doma par brīvu Latviju. In: ANITA Freiberga (red.). Latvijas Jūrniecības Gadagrāmata 2018. Rīga 2019, 388.-398. lpp.

${ }^{9}$ Sk., piem.: EDGARS ANDERSONS. Latvijas vēsture 1920-1940: Ārpolītika. II sēj. Stokholma 1984, 504. lpp.

${ }^{10}$ Sk. Alfrēda Bīlmaņa saraksti ar jūrniecības un diplomātiskajiem darbiniekiem. Latvijas Nacionālais arhīvs, Latvijas Valsts vēstures arhīvs, Rīga (turpmāk - LNA LVVA), 293-1-1931, 293-1-1946, 293-4-225 u. c.

${ }^{11}$ Sk., piem.: Kug̣īpašnieka Jāṇa Zalcmaṇa vēstule A. Bīlmanim. Stokholma, 08.01.1945. Ibidem, 293-1-1931, 5. lp.; Latvijas Saimniecisko Darbinieku Apvienības (LSDA) Kuǵniecības sekcijas uzaicinājuma paraugs, 1951. Ibidem, 293-1-1454, 9. lp.; LSDA priekšsēdētāja J. Zalcmaṇa vēstule Latvijas sūtnim Vašingtonā Jūlijam Feldmanam. N̦ujorka, 23.05.1951. Ibidem, 12. lp.

${ }^{12}$ Sk., piem., latviešu jūrnieku saraksti ar Latvijas sūtniecību Vašingtonā. Ibidem, 293-1-1945, 293-1-1946.

${ }^{13}$ Sk., piem.: A. S. [iespējams, AUGUSTs ŠMITS]. Latvijas kuǵniecība agrāk un tagad. In: Latvju Vārds, 07.04.1948., 4. lpp. 
${ }^{14}$ Šajās norisēs centrālā figūra neapšaubāmi ir tāljūras kapteinis Imants Balodis (1924-2001), kurš 1988. gadā nodēvēts par Rietumvalstīs pēdējo aktīvo latviešu jūrnieku - biežs viesis Latvijā, daudzu ceremoniju un sarīkojumu dalībnieks un goda viesis kā Rīgā, tā citviet Latvijā, uzturējis jo sirsnīgas attiecības arī ar savu dzimto pusi un pirmo skolu Kalnciemā. Pateicoties savām zināšanām un ilggadējai pieredzei Rietumvalstu jūrniecības nozarē, Trešās atmodas gados I. Balodis Latvijā kḷuva par nenoliedzamu autoritāti jūrniecības lietās, uzsākdams aktīvu sadarbību gan ar Latvijas, gan Igaunijas jūrniecības valsts un privātajām struktūrām: 1994. gadā, piemēram, līdzējis nodibināt sakarus ar Rietumiem kādam jaunam igauṇu rēderim Pērnavā, pēc tam sešas nedēḷas strādājis Latvijas Republikas Satiksmes ministrijas Jūrniecības administrācijā, pētot Latvijas ostu problēmas, līdztekus tam piedalījies Latvijas Jūras akadēmijas pirmā izlaiduma Valsts eksaminācijas komisijas darbā... Un tā - gandrīz katru gadu 90. gadu pirmajā pusē un vidū.

${ }^{15}$ Visbiežāk gan tas, saprotams, darīts vai nu pēc šo darbinieku aktīvās profesionālās darbības posma beigām, kad daudzināmā persona atzīmēja kādu lielāku un apaḷāku dzìves gadskārtu, vai arī cildināmajam darbiniekam aizejot aizsaulē.

${ }^{16}$ Galvenokārt tie bija nelieli, publicistiski raksti par bijušās Latvijas Republikas tirdzniecības flotes kug̛u, kā arī Latvijas Republikas pilsoṇu īpašumā vēlāk nonākušu peldlīdzekḷu nogrimšanu pasaules jūrās dažādu valstu dienestā (šādi raksti trimdā atkal un atkal parādījās vismaz līdz 70. gadu beigām), retāk - publikācijas par latviešu jūrnieku nodarbinātības problēmām Rietumvalstīs (raksturīgas trimdas sākumposmam līdz apmēram 50. gadu sākumam, kad aizvien vairāk latviešu jūrnieku uzsāka vai jau bija uzsākuši sekmīgu kāpienu pa karjeras kāpnēm mītnes valstu kuǵniecības uznēemumos vai dienestos un tālab šĩs problēmas vairs neškita tik aktuālas vismaz gana būtiskas, lai tām veltītu plašu uzmanību trimdas plašsaziņas jeb mediju vidē).

${ }^{17}$ Aktīvie jūrnieki sabiedriskajai dzīvei līdz pat 60. gadu vidum varēja pievērsties reti, jo vairākumā gadījumu piederēja pie paaudzes, kas tobrīd vēl aktīvi brauca jūrā, bet braukšana jūrā nozīmēja ilgstošu prombūtni no mītnes zemes, tautiešu sabiedrības un krasta vispār, un tas liedza jūrniekam nodarboties ar aktīvu sabiedrisko vai pētniecisko darbību.

${ }^{18}$ Tie glabājas LJVA materiālu kopā Rīgas vēstures un kuğniecības muzeja Latvijas kuğniecības vēstures nodaḷas zinātniskajā arhīvā (turpmāk - RVKM LKVN ZA).

${ }^{19}$ Trimdas presē, piemēram, vairākus visai saturīgus rakstus par jūrniecības vēstures tēmām, īpaši pievēršoties Otrā pasaules kara un trimdas posmam, publicējis kāds K. Arklinšs (sk., piem.: K. ARKLIN̦Š. Zemūdenes gremdē Latvijas kuǵus: Latvijas kuğu gaitas Rietumu okeānos [I-III daḷa]. In: Laiks, 19.07.1972., 8. lpp.; 22.07.1972., 26.07.1972., 8. lpp.), par šo autoru neko vairāk pagaidām nav izdevies noskaidrot. Vai tas ir kāda no mums zināmajiem trimdas jūrniecības vēstures pētniekiem, īsto vārdu maskējot aiz pseidonīma? Tāpat rodas jautājums, kas ir "S", kurš "Laikā" 16 (!) rakstos (sākumraksts un 15 tā turpinājumi) publicējis izvērstu pētījumu (raksts noteikti nav tikai liecība vai atmiņstāsts) par motorkuǵa "Hercogs Jēkabs" gaitām? (Sk.: S. Starp divām pasaulēm: Hercoga Jēkaba gaitas mūsu tirdzniecības flotē [I-XI daḷa]. In: Laiks, 09.02.1972., 8. lpp.; 12.02.1972., 8. lpp.; 16.02.1972., 8. lpp.; 19.02.1972., 8. lpp.; 23.02.1972., 8. lpp.; 26.02.1972., 8. lpp.; 01.03.1972., 8. lpp.; 04.03.1972., 8. lpp.; 08.03.1972., 8. lpp.; 11.03.1972., 8. lpp.; 15.03.1972., 8. lpp.; 18.03.1972., 8. lpp.; 22.03.1972., 8. lpp.; 25.03.1972., 8. lpp.; 29.03.1972., 8. lpp.; 01.04.1972., 8. lpp.) Zināms vien tas, ka viņš dramatisko 1940. gada notikumu laikā bijis "Hercoga Jēkaba" apkalpes loceklis.

${ }^{20}$ Sk.: Paul F. DambeKaln. Beyond the Horizons: the Story of our Family. Madison 1974; MANFREDS ZICHMANIS. Brāli Zēbergi: personības, burinieki, tvaikoṇi. Toronto 1986. Tas pats vācu valodā: MANFRED ZichMANIS. Seeberg. Nachtrag zum Buch "Gebrüder Seeberg". Toronto 1985.

${ }^{21}$ Piem.: E. T. Dižens latviešu jūrniecības sniegums. In: Brīvā Latvija, 16.03.1987., 2. lpp.

${ }^{22}$ KĀRLIS KụAVIN̦Š. Latvijas kuğu likteni. In: EDGARS DunSDORFS (galv. red.). Archīvs: raksti par latviskām problēmām. XI sējums: Zelts, tiesības. Melburna 1971, 127.-156. lpp. 
${ }^{23}$ Edgars Andersons. Senie Kurzemnieki Amerikā un Tobāgo kolonizācija. Stokholma 1970; EDGARS ANDERSONS. Tur plīvoja Kurzemes karogi. N, Nujorka 1970.

${ }^{24}$ Tuvāk sk. bezautora rakstā "Latviešu jūrniekus pieminot" (2015) Rietumos mītošo latviešu veidotā portālā "kancele.lv". Pieejams: http://www.kancele.net/jurnieki.html (skatīts 20.04.2017.). Iespējams, šis E. Andersona manuskripts glabājas Hūvera institūta arhīva Baltijas valstu kolekcijā Stenfordā (Baltic States Collections at the Hoover Institution Archives), kur nonākusi vismaz daļa vēsturnieka arhīva.

${ }^{25}$ Edgars Andersons. Divkosība draudzības maskā [II dala]. In: Laiks, 30.08.1980., 8. lpp.; EDGARS ANDERSONS. Divkosība draudzības maskā [IV daḷa]. In: Laiks, 06.09.1980., 8. lpp.; EDGARS ANDERSONS. Divkosība draudzības maskā [V daḷa]. In: Laiks, 10.09.1980., 8. lpp.

${ }^{26}$ Piem.: EDGARS ANDERSONS. Baltijas valstu liktenis vēstures svaru kausos. In: Laiks, 01.06.1983., 3. lpp.

${ }^{27}$ No 1957. gada līdz savai nāvei 1989. gadā E. Andersons aktīvi sadarbojies gan ar ASV federālo valdību, gan Kalifornijas štata valdību kā konsultants vēstures jautājumos.

${ }^{28}$ Sk., piem.: HEINZ VON BASSI. Die Auswirkungen der deutschen Seeüberwachung auf den Seehandel Lettlands nach Ausbruch des Zweiten Weltkrieges. In: Marine-Rundschau 1977, No. 5, S. 242-245.

${ }^{29}$ Minēsim kaut vai pazīstamo šveiciešu militārvēsturnieku Jirgu Meisteru (sk., piem.: JÜRG MeISTER. Was kostet die Freiheit? Die Schicksal der baltischen Staaten als Warnung. In: Allgemeine Schweizerische Militärzeitschrift 137, (December, 1971), No. 12, pp. 872-873; JÜRG MEISTER. Den Lettiska flottan 1918-1941. In: Tidskrift i sjöväsendet (June 1974), No. 137, pp. 295-307 etc.).

${ }^{30}$ Sk.: A. Vai taps latviešu kuǵniecības vēsture? In: Laiks, 24.09.1975., 3. lpp.

${ }^{31}$ Pūlini, Veides, Graudi u. c.

32 Voldemāra Ploša vēstule J. Birzem, N,ujorka, [ap 1968-1969]. RVKM LKVN arhīvs.

${ }^{33}$ Ibidem.

${ }^{34}$ Protams, atskaitot intereses trūkumu konkrēti par jūrniecības vēsturi, šĩs problēmas, īpaši avotu jautājums, bija gaužām raksturīgas visai trimdas historiogrāfiskajai videi un tās pētnieku pulkam.

${ }^{35}$ Trīs sējumi LJVA materiālu kopā bez uzskaites apzīmējuma.

${ }^{36}$ Piem.: ARvīDs KĀRKLIN̦Š, HeINCS FON BASSI. Pirmais un pēdējais... Maiga un Ķegums. In: Laiks, 27.05.1981., 6. lpp.; ARVİDS KĀRKLIN̦š, HEINCS FON BASSI. Rekviēms Sarātovam. In: Laiks, 12.04.1980., 8. lpp;; ARVĪDS KĀRKLIN̦Š, HEINCS FON BASSI. Latviešu jūrnieku drāmas pasaules jūrās. In: Laiks, 07.01.1981., 4. lpp.

${ }^{37}$ Heinrihs Liberts (1894-1969) un Arvalds Mārtiņš Kalniņš (1917-2006) Anglijā, Alvars Mastinšs (1905-1992) Vācijā, Kārlis Kalacis (1894-1971), Voldemārs Orle (1889-1970) un V. Štāls.

${ }^{38}$ Pagaidām trūkst ziṇu, vai gaisā virmojuši jelkādi nodomi līdzīgu - Latvijas jūrniecības vai vismaz tautsaimniecības vēstures materiāliem paredzētu - krātuvi izveidot citviet, piemēram, kādas lielākas organizācijas paspārnē, līdzịgi kā tas bija ar Biezaišu ǵimenes veidoto Latviešu mūzikas krātuvi, kas kādu laiku darbojās kā Amerikas Latviešu apvienības struktūrvienība.

${ }^{39}$ LJVA Noteikumi (Statūti), pieṇemti 27.11.1966. Kārdifā. RVKM LKVN ZA.

${ }^{40}$ A. Vai taps latviešu kuğniecības vēsture?

${ }^{41}$ A[RVALDS] M[ĀRTIN̦Š] K[ALNIN̦Š]. Latvijas jūrniecības vēstures archīva 10 gadi. In: Londonas Avīze, 17.12.1976., 3. lpp.

${ }^{42}$ Sk., piem.: Jūrniecības mūzejs. In: Jūrnieks 1930, Nr. 12, 388.-389. lpp.

${ }^{43}$ Sk.: Jūrniecības muzeja biedrības draugiem un labvēḷiem. In: Jūrnieks 1934, Nr. 1, 36.-38. lpp.

${ }^{44}$ LJVA Noteikumi (Statūti). RVKM LKVN arhīvs.

${ }^{45}$ LJVA oficiālo biedru saraksts, sastādīts pēc 2001. gada, 1.-7. lp. RVKM LKVN arhīvs. 
${ }^{46}$ K. ARKLIN̦Š. Plāno Latvijas jūrniecības vēsturi: līdzstrādnieki visās pasaules malās. In: Laiks, 30.09.1978., 6. lpp.

${ }^{47}$ K[ALNIN̦Š], Latvijas jūrniecības vēstures archīva 10 gadi, 3. lpp.

${ }^{48}$ RVKM LKVN arhīvs. Nolikums par LJVA struktūru, sastādīts 1966.27.XI Kārdifā (vēlāk papildināts), 1.-3. lp.

${ }^{49}$ KALNIN̦Š, Latvijas jūrniecības vēstures archīva 10 gadi. Saistībā ar šo konferenci sk. arī H. fon Basi nolasītā referāta tekstu par Latvijas kara un tirdzniecības flotes likteni Otrā pasaules kara laikā: HEINZ VON BASSI. Das Schicksal der lettischen Kriegs- und Handelsflotte im Zweiten Weltkrieg. In: The Third Conference on Baltic Studies in Scandinavia. Vol. 1: History Section. Stockholm 1977, S. 212-219.

${ }^{50}$ Par to, ar kādu aizrautību un entuziasmu LJVA līdzstrādnieki gādāja par materiālu krājuma papildināšanu, liecina organizācijas darbinieku sarakste ar materiālu sniedzējiem (sk. LJVA materiālus RVKM LKVN ZA un arhīvā). Tā, piemēram, kādā vēstulē Lielbritānijas latviešu mācītājam, kurš zinojis Arvaldam Kalninam par nodomu apmeklēt kādu vecu latviešu jūrnieku, LJVA generālsekretārs vinu stingri noinstruējis, kas ir tās zinas un lietas, kas no vecā jūrnieka būtu visnoderīgākās Latvijas jūrniecības vēsturei: "Jūs domājiet, ka vina rīcībā ir Lloyds reğistri. Tas ir interesanti, bet esam tos jau izsijājuši [...]. Daudz interesantāk un lietderigāk būtu, ja kungs Skapens varētu dot kādas personigas atmiņas no saviem jūrnieka laikiem uz Latvijas kuǵiem - to gaitas u.t.t." (Arvalda Kalniņa vēstule prāvestam R. Muzikam Londonā, Kārdifa, 06.09.1977. RVKM LKVN ZA, Ja 11, 136. lp.)

${ }^{51}$ KALNIN̦Š, Latvijas jūrniecības vēstures archīva 10 gadi.

${ }^{52}$ Respektīvi, kā arhīva vai muzeja materiāls - muzeālija.

${ }^{53}$ Kā ārkārtīgi strīdīgas un tādēl pētnieciski pašas interesantākās jāatzīmē LJVA pierakstītās kapteiņa Sergeja Bola atmiņas, kas sniedz Latvijas diplomātisko pārstāvniecību dokumentos atrodamajām ziņām pretēju versiju par daudzu notikumu gaitu un niansēm. Sk.: RVKM LKVN ZA, Ja 2 (materiāli par Friča Grauda rēdereju).

${ }^{54}$ Tuvāk sk.: ARNOLDS AIZSILNIEKS. Vai mums ir par daudz organizāciju? In: Latvju Ziṇas, 25.08.1949.

55 Četru bojāgājušo jūrnieku lịki netika atrasti.

56 "Staburaga" vecskautu grupas vecākais.

${ }^{57}$ IMANTS BĒRZIN̦Š. Latviešu svētceḷnieki Luingas salā. In: Brīvā Latvija, 26.06.1989., 4. lpp.

${ }^{58}$ A. Kalniņa vēstule Rolandam Blezūram, Kārdifa, 23.05.1983. RVKM LKVN ZA, Ja 11, 117. lp.

${ }^{59}$ IMANTS BĒRZIN̦š. Skotijā lielā sirsnībā piemin latviešus. In: Laiks, 10.01.1987., 6. lpp.

${ }^{60}$ G. G. ARĀJS. Svētcel̦ojums uz Luinga salu. In: Latvija Amerikā, 11.10.1986., 14. lpp.

${ }^{61}$ Sk. Nikolaja Doičeva vēstuli LJVA vadītājam A. Kalniņam, Kroulija, 23.03.1985. RVKM LKVN ZA, Ja 11, 107. lp.

${ }^{62}$ Sk. N. Doičeva saraksti ar ziedotājiem un sabiedriskajiem darbiniekiem un ziedotāju sarakstus. Ibidem, 16.-95., 107. 1p.

${ }^{63}$ Lēmumi Straumēnos: ELJA Anglijas nodaḷas 29. sapulcē pienemtās rezolūcijas. In: Londonas Avīze, 02.12.1983., 3. lpp.; Latvijas likteņu izgaismošana. In: Londonas Avīze, 04.02.1984., [1.] lpp.; Luing's care impresses Latvians. In: The Oban Times, 14.07.1983., p. [1].

${ }^{64}$ Kuğa avārijas atcere. In: Laiks, 10.09.1986., 7. lpp.

${ }^{65}$ Sk., piem.: Divu tautu saderība. In: Brīvā Latvija, 13.10.1986., 4. lpp.; Moving ceremony on Luing as Latvians remember lost crewmen. In: The Oban Times, 18.09.1986., p. [1]; Moving ceremony in the Kirk at Kilchattan. In: The Sunday Post, 28.09.1986., p. 22; ARĀJS, Svētceḷjums uz Luinga salu; BĒRZIN̦š, Skotijā lielā sirsnībā piemin latviešus u. c.

${ }^{66}$ Latviešu apmeklējuma programma Luingas salā 3. jūnijā 1989. g. RVKM LKVN arhīvs; Latvia's Debt To The Island Of Luing. In: The Sunday Post, 18.06.1989., p. [1]. 
${ }^{67}$ 1998. gada 13. septembra Luinga salas apmeklējuma un piemiṇbrīža programmiņa. RVKM LKVN arhīvs.

${ }^{68}$ Par šo profesora E. Andersona darbības līniju galvenokārt sk.: ANDERsons, Senie Kurzemnieki Amerikā un Tobāgo kolonizācija, 341.-348. lpp.

${ }^{69}$ Ibidem, 341.-342. lpp.

${ }^{70}$ Ilze Bernsone. No Kārdifas uz Rīgu. In: ANITA FreIBERgA (red.). Latvijas Jūrniecības Gadagrāmata 2012. Rīga 2013, 376. lpp.

${ }^{71}$ LJVA oficiālo biedru saraksts, 6.-7. lp. RVKM LKVN arhīvs.

${ }^{72}$ Sk., piem.: ARVIS POPE. Jūrnieki, atsaucieties! In: Laiks, 15.03.1989., 8. lpp.

${ }^{73}$ Sk.: ARvis PoPE. Kā es nonācu pie jūrniecības vēstures. In: Laiks, 25.05.1991., 6. lpp.

${ }^{74}$ M. B. Arvis Pope, LKF priekšsēža vietnieks, ASV. In: Laiks, 17.04.1991., 3. 1pp.; M. B. Pitsburga (PA). In: Laiks, 22.05.1991., 2. lpp.

${ }^{75}$ Dāvja Beitlera intervija ar bijušo RVKM LKVN vadītāju Ilzi Bernsoni un Intu Kārkliṇu Rīgā 30.03.2017.

${ }^{76}$ A. Kalniņa vēstule I. Bernsonei, Kārdifa, 12.1993. RVKM LKVN arhīvs.

77 BERnSONE, No Kārdifas uz Rīgu, 375. lpp.

${ }^{78}$ A. Kalniṇa pavadvēstule sūtijjumam, Kārdifa, 20.11.1991.; kā Latvijas institūciju puses pārstāvis un sūtījuma pieņēmējs parakstījis arī A. Pope. RVKM LKVN arhīvs.

${ }^{79}$ I. Bernsones vēstule A. Kalniņam, Rīga, 17.12.1991.17.XII. RVKM LKVN arhīvs.

${ }^{80}$ A. Kalniņa vēstule I. Bernsonei, Kārdifa, 27.12.1993. RVKM LKVN arhīvs.

${ }^{81}$ Akts par LJVA materiālu nodošanu RVKM LKVN un ieskaitīšanu nodaḷas ZA ar šifru "Ja"; 20.06.1995., parakstijjuši A. Kalniņš un I. Bernsone, vīzējusi Klāra Radziņa. RVKM LKVN arhīvs.

82 BERnSONE, No Kārdifas uz Rīgu, 378. lpp.

${ }^{83}$ Dāvja Beitlera intervija ar I. Bernsoni un I. Kārkliņu Rīgā 30.03.2017.

${ }^{84}$ Ilze BERnSONE (galv. red.). Latvijas jūrniecības vēsture 1850-1950: enciklopēdija. Rīga 1998; ILZE BERNSONE (galv. red.). Latvijas jūrniecības vēsture 1950-2000: enciklopēdija. Rīga 2003.

\section{SUMMARY}

The Latvian exile after the Second World War to the West in 1939-1945 brought there many Latvians of maritime professions and the history of this economical sector of Latvian state and people. These Latvians quite actively participated in the work of maintaining Latvian self-confidence in the exile, simultaneously safeguarding the historical memory of their profession and interests.

The Latvian historical maritime heritage was researched and popularized, first of all, by Latvian seamen - mainly the active and retired captains (Arvalds Kalniņš, Voldemārs Štāls, Alvars Mastiņš, Voldemārs Plosis, Imants Balodis and others); secondly, by the descendants of the Latvian seamen - they wrote books about family history (the main examples - "Beyond the Horizons: the Story of Our Family" (1974) by Paul F. Dambekaln, "Seeberg Brothers: Personalities, Sailing ships, Steamers" (1985) by Manfred Zichmanis and others); thirdly, by the professional historians and other academically trained and graduated humanities researchers (historian, Professor Edgar Andersons (articles about Latvian ships in the context of policy perpetuated by the Western powers - the United States of America and United Kingdom), lawyer Karlos (Kārlis) Kḷaviņš (articles about 
Latvian ships after the Second World War) and others. Baltic-German historian Heinz von Bassi and public activists of Latvian exile also contributed to this work.

Particularly notable is the organization "Latvian Maritime History Archives" (founded in 1966 in Cardiff, Wales) and its enthusiastic leader - General Secretary Arvalds Kalniņš. The statutes of the society determined that the society "is a voluntary association founded to further the interests of persons concerned in the subject of ships, seamen and history or shipping of the Latvian Nation within or without the State of Latvia. The purpose of the Society is to assemble in a group amateurs and professional historians who are interested in the study of Latvian maritime subjects." In the active period (until about 1991), "Latvian Maritime History Archives" collected thousands of historical documents from various countries and continents. From 1990-1991 (when the exile-period in the Latvian history ended) to about 2012, all of the materials from "Latvian Maritime History Archives" and many private materials pertaining to the history of Latvian navigation gradually became a part of the Department of Latvian Navigation collections at the Museum of History of Riga and Navigation. At this time - the beginning of the 1990s intellectual achievements of the aforementioned activities in exile became a part of the culture and economy in the renewed Republic of Latvia. 